This item was submitted to Loughborough's Research Repository by the author.

Items in Figshare are protected by copyright, with all rights reserved, unless otherwise indicated.

\title{
A new curriculum for technology education in Schleswig-Holstein
}

PLEASE CITE THE PUBLISHED VERSION

PUBLISHER

(c) Loughborough University

LICENCE

CC BY-NC-ND 4.0

REPOSITORY RECORD

Hopken, Gerd. 2019. "A New Curriculum for Technology Education in Schleswig-holstein”. figshare. https://hdl.handle.net/2134/1535. 
This item was submitted to Loughborough's Institutional Repository by the author and is made available under the following Creative Commons Licence conditions.

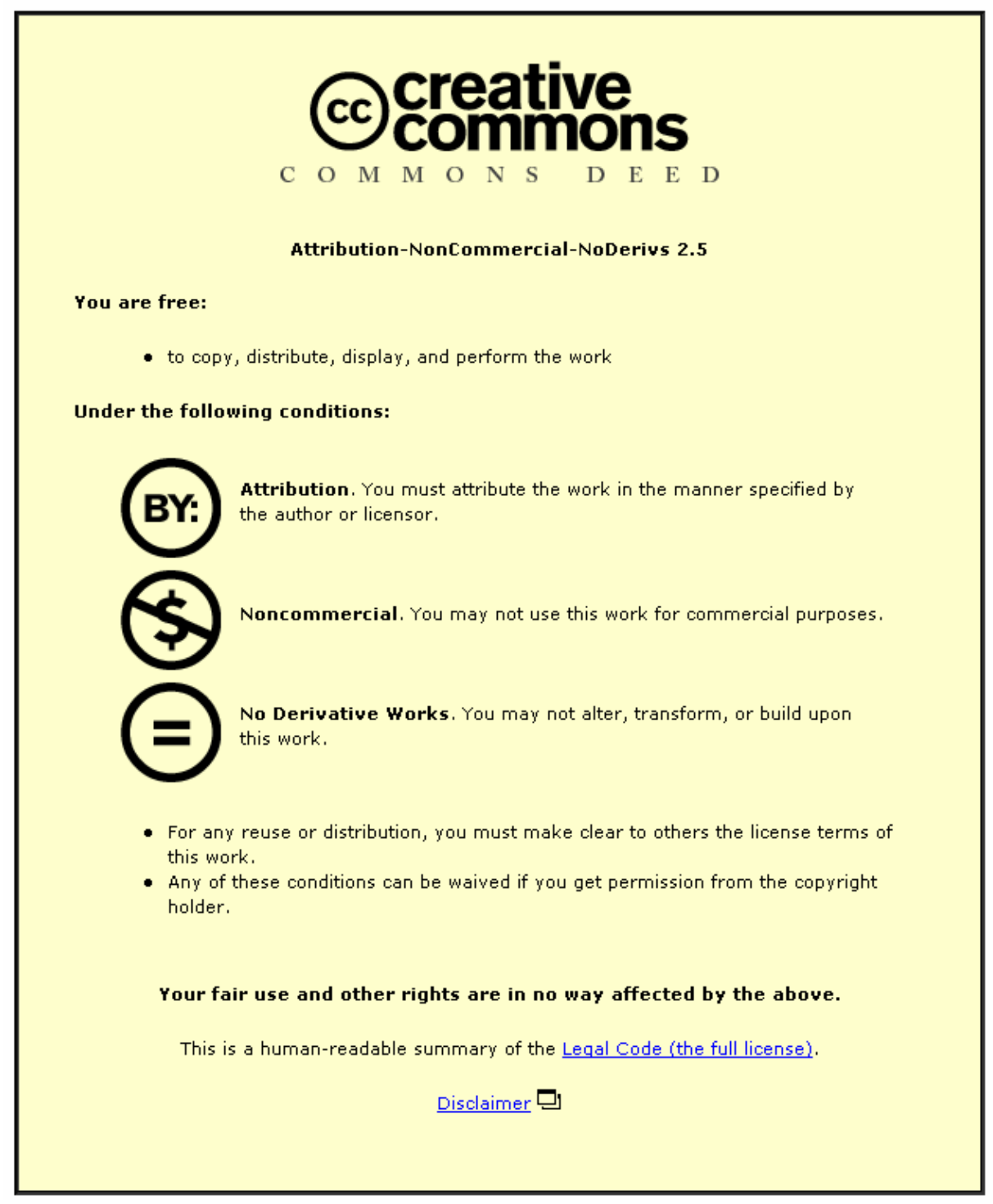

For the full text of this licence, please go to: http://creativecommons.org/licenses/by-nc-nd/2.5/ 


\title{
A new curriculum for technology education in Schleswig- Holstein
}

\author{
Gerd Höpken
}

Institut für Technik und ihre Didaktik, Bildungswissenschaftliche Hochschule Flensburg Universität, Germany

\begin{abstract}
The existing Curriculum - valid since 1986 - is structured in fields of action: working and production, transportation and traffic, building and built environment, supply and disposal, information and communication. 1992 a revision of all curricula began. Guidelines for this revision were:

1 New curricula sbould lead to a discussion on core problems (e.g. basic values of living togetber in peace in different cultures; preservation of the elements of life; future cbange of economic, technological and social conditions; equal status of women and men; the right of all buman beings to form their political, cultural and economic living conditions).

2 New curricula should secure a common basic education.

3 New curricula sbould enable the interweaving of learning experiences.

4 New curricula sbould enable co-operation across the bounds of scbool subjects.

5 New curricula sbould relieve lessons.
\end{abstract}

\section{The German Educational System}

After World War II, the Federal Republic of Germany was established after the model of the United States of America. Figure 1 shows the federal states ("Länder") and their population figures. In the German Federal Republic the federal states are independent in educational matters.

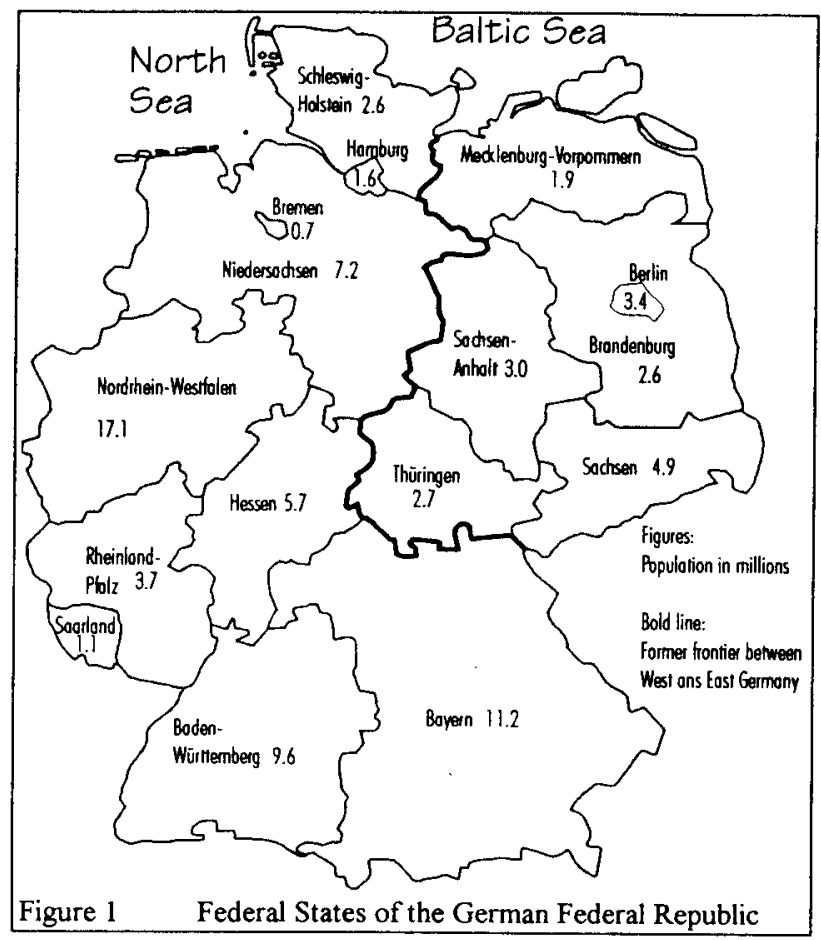

In spite of the independence, the educational system in the federal states is nearly the same (Figure 2). Although in all states there are comprehensive schools, the normal system consists of a primary school and three branches of secondary schools:

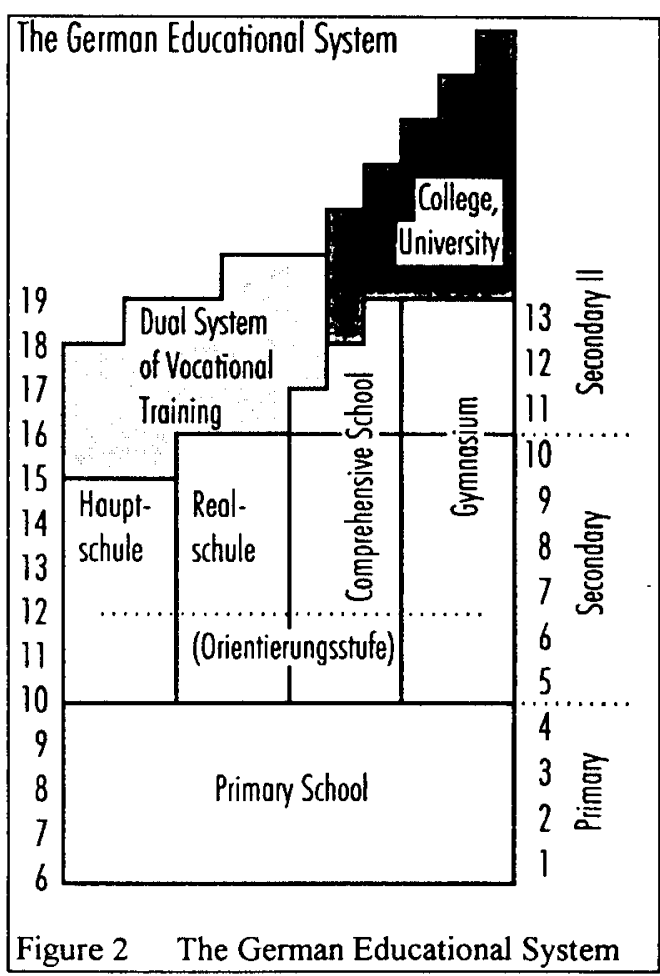

Hauptschule (general secondary school), Realschule and Gymnasium (high school). In some states the first two years of secondary school form a school on its own, the Orientierungsstufe.

The school leaving certificate of the Hauptschule entitles the student toenter intoan apprenticeship. The same is true for the Realschule, although under certain conditions the student can go to the Gymnasium. The leaving certificate of a Gymnasium entitles the student to go to a college or university. Today approximately one third of the pupils attend each type of school Hauptschule, Realschule and 
Gymnasium. Only a few pupils attend comprehensive schools. is taught only in Hauptschule and Realschule. (Figure 3)

In most of the federal states technology education

\begin{tabular}{|c|c|c|c|c|c|c|c|c|c|}
\hline & Primary School & \multicolumn{6}{|c|}{ Socondary Schools } & \multirow{2}{*}{$\begin{array}{l}\text { School } \\
\text { Type }\end{array}$} & \\
\hline State & \begin{tabular}{|l|l|l|l|}
1 & 2 & 3 & 4 \\
\end{tabular} & 5 & 6 & 18 & $\begin{array}{ll}8 & 1 \\
\end{array}$ & $9 \mid 10$ & \begin{tabular}{|l|l|l|}
11 & 12 & 13 \\
\end{tabular} & & \\
\hline Boden- & Q1D & & & & & 7 & & $\begin{array}{l}\text { Hauptschule } \\
\text { Reobschule }\end{array}$ & \\
\hline & & & & & ] & E & & Gesamtschule & \\
\hline Boyern & \begin{tabular}{l|l|l|l|}
$\mathbf{D}$ & $\mathbf{0}$ & $\mathbf{0}$ & $\mathbf{m}$ \\
\end{tabular} & 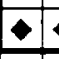 & - & 4 & -1 & - & & Houptschule & \\
\hline & 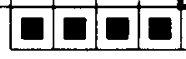 & & & I & a & 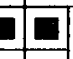 & & Houptschule & \\
\hline Berlin & & & & L & DE & $\mathbf{a}$ & & Reolschule. & \\
\hline & & & & T & at & 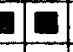 & & Gesamtschule & \\
\hline & \begin{tabular}{l|l|l|l|}
0 & 0 & 0 \\
\end{tabular} & & & IE & 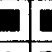 & $\mathbf{a}$ & & Houptschula & \\
\hline Brondenburg & & & & 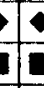 & -1 & 9 & \begin{tabular}{|l|l|l|}
$\mathbf{0}$ & $\mathbf{a}$ & $\mathbf{0}$ \\
$\mathbf{0}$ & $\mathbf{0}$ & $\mathbf{a}$ \\
\end{tabular} & $\begin{array}{l}\text { Reolschule } \\
\text { Gesamtschule }\end{array}$ & \\
\hline & & & & & $\mathbf{1}$ & $\mathbf{a}$ & & Houptschule & Technology is: \\
\hline Bremen & & EI & & I & 7 & 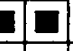 & & Roobsculo & $P 7$ Comouknory subient \\
\hline & & 10 & & & 도 & $\mathbf{n}$ & & Gymnosium & \\
\hline Hamburg & & & & & & \begin{tabular}{r|r}
$\mathbf{a}$ \\
$\mathbf{9}$ \\
\end{tabular} & & $\begin{array}{l}\text { Houptschule } \\
\text { Roolschule }\end{array}$ & $\begin{array}{l}\text { One of compulsory } \\
\text { subjocts to choose from }\end{array}$ \\
\hline & & L & & & a. & $\mathbf{0}$ & & Gesamtschule & - Optional subject \\
\hline & \begin{tabular}{l|l|l|}
$\mathbf{D}$ & $\mathbf{0}$ \\
\end{tabular} & EI & I & a & t & 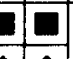 & & Haupptschule & Part of an integrated subject \\
\hline Hessen & & D: & & $=$ & 01 & -1 & & Reotschule & 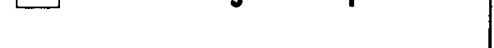 \\
\hline & & & & & $\square<$ & $\bullet$ & & $\begin{array}{l}\text { Gymnosium } \\
\text { Gesamtschule }\end{array}$ & Part of an optionol integrated subject \\
\hline $\begin{array}{l}\text { Mecklenburg } \\
\text { Vorpommern }\end{array}$ & & & & & & & & $\begin{array}{l}\text { Houptschule } \\
\text { Roolschulo } \\
\text { Gymnosium }\end{array}$ & $\begin{array}{l}\text { [ Con be fought, if the personal and } \\
\text { spotiol focilties are avoilable }\end{array}$ \\
\hline & & & & & & 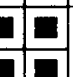 & & Hauplschule & \\
\hline Niedersachsen & & & & 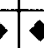 & & -1 & & Gymnosium & \\
\hline & $\mathbf{\square} \mathbf{\square}$ & & & & & 4 & & Houptschule & \\
\hline Nordrhein- & & & & 1 & L & + & & Reolschule & \\
\hline Westialen & & & & & & $-\bullet$ & 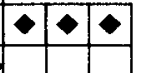 & $\begin{array}{l}\text { Gymnosium } \\
\text { Gesamtschule }\end{array}$ & \\
\hline & \begin{tabular}{|l|l|l|}
$\mathbf{D}$ & $\mathbf{0}$ & $\mathbf{0}$ \\
\end{tabular} & Di & a & 4 & 盗 & 4 & & Houptschule & \\
\hline Rheinland- & & $\bullet$ & -1 & 6 & +1 & $-\bullet$ & & Roolschute & \\
\hline Pfolz & & $\bullet$ & -1 & 10 & -1 & $\bullet \bullet$ & & Gymnasium & \\
\hline & & EI & at & to & ] & a & & Gesamtschulo & \\
\hline Soorland & \begin{tabular}{|l|l|}
$\mathbf{D}$ & $\mathbf{D}$ \\
\end{tabular} & & & J & 15 & 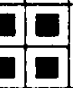 & & $\begin{array}{l}\text { Houptschule } \\
\text { Reolschulo }\end{array}$ & \\
\hline Sachsen & & & & & 1 & $+\div$ & & $\begin{array}{l}\text { Reolschule } \\
\text { Gymnosium }\end{array}$ & \\
\hline Sachsert- & & & & 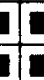 & at & $\square$ & & $\begin{array}{l}\text { Hauptschulo } \\
\text { Realschula }\end{array}$ & \\
\hline & & & & & & 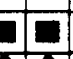 & & Gymnosium & \\
\hline Schloswig- & \begin{tabular}{|l|l|l|l|}
$\square$ & $\square$ & 0 \\
\end{tabular} & & & & & 4 & & Houptschule & \\
\hline Holstein & & & & 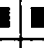 & EI & $\mathbf{a}$ & & Realschule & \\
\hline & & & & 15 & at & $\mathbf{a}$ & & Gesamtschule & \\
\hline Thüringen & & & & 1 & 01 & a & & Houptschule & \\
\hline
\end{tabular}




\section{Revision of Curricula in Schleswig-Holstein}

To meet the common problems of today's schools, the Schleswig-Holstein Ministry of Education decided to revise all curricula of schools providing a general education. The revision began with an evening opening ceremony in the castle of Kiel on December 6, 1991. The inaugural address was given by Secretary of State Bodo Richter: Educational policy for the world of tomorrow. Only two more speeches were held that evening. Hans Heinrich Driftmann, chair of the Schleswig-Holstein commission of educational policy of the society of employers' associations, spoke on "Demands of the economy for a future oriented educational policy". Martin Baethge, professor of sociology of Göttingen university- described "Educational expectations and demands for qualifications - educational sociological cornerstones for tomorrow's society".

The event continued on the next day at Kiel university. Here the framework for the revision of the curricula was explained by Klaus Karpen, head of the department "basic problems of educational policy" at the ministry of education. He referred to the Prime Minister's policy statement on internal school reform. The main targets were:

- opening lessons in respect of subject matter, methods, and organisation

- discussing new tasks and challenges

- expanding cross curricular and cross school branches co-operation

- democratising school life

The revision of the curricula was to take place in the Sekundarstufe I (junior secondary schools, forms 6 - 10 of Hauptschule, Realschule, Gymnasium, and Gesamtschule). The basic ideas are:

\section{The new curricula should come to terms with} core problems

Today's views on life and educational conceptions are hardly agreed on any longer. The concept of orientation toward science is no longer sufficient as the only reference point for teaching and learning. Nevertheless curricular work needs a common base. Such a base could be formed by working on core problems. Present core problems are:

- Basic values of human living together, in particular peace, human rights and living together in a world with different cult ures, social systems, peoples, and nations as an individual and global task.

- Preservation of the natural fundamentals of life, of one's own health and other people's wellbeing.

- The future change in economic, technological, and social conditions of life and their impact on shaping conditions of life.
- Equal status for women and men, boys and girls, in family, vocation and society.

- The right of all human beings to organise their own political, cultural, and economic conditions of life, their participation and joint responsibility in all areas of life.

\section{The new curricula sbould secure a common basic education}

The explosion of knowledge and accelerated change hamper a joint participation of all people in culture, economy and society. That is the reason why cross school branches common basic education is necessary. An education in which the student can develop factual competence, judgement, ability to act and communicate. The target is to enable the student to participate in common assignments in school, vocation, and society.

3. The new curricula sbould belp to connect the experiences of life

While in former times for most of the students school was the only important place of learning besides neighbourhood, today's students live in multiple worlds and correlation of learning.

\section{The new curricula should strengthen cross} curriculum co-operation

Subjects remain the most important way in school, to provide a variety of information for teaching and learning. The academic disciplines and their didactic studies therefore remain the basic frame of orientation for curricular work. The contents of the curriculum must have - in addition to the subject purposes - a discernible relation to educational targets and have to come to terms with the core problems. That is the reason why the work of the commission for each school subject is accompanied by permanent co-ordination of related school subjects.

\section{The new curricula sbould relieve teaching}

Today great demands from everywhere are made on schools. A Place for new subject matters can only be found when former ones are discarded. The different school branches have to shape a distinct profile.

Learning happens in different ways and individually. Curricula must make room for free learning, internal differentiation, and individualised learning. Teachers need more free room for creativity.

6. The new curricula should strengtben profile and co-operation of scbool subject, scbool stages and scbool branches

The new curricula ought to show what has to be done in the lessons in a clear and intelligible way. But they do not substitute for the planning of 
lessons or academic articles.

There will be curricula for each subject in each school branch, but they have to be well co-ordinated in order to secure a common basic education. The curricula will get a new structure: After an introduction explaining the position of the subject within the legal educational task the minimum requirements on graduated common basic education will have to be named. Not till then will the school branch specific structured learning program follow.

The curricula must be made in a way that a sensible layman can understand them and can estimate their intentions and organisation. meaning for school

2 Principles of education in regard of peace

3 Peace as an aspect of subjects, the example of sciences

4 Projects in peace education

5 Overdevelopment or surviving

6 Learning in a world which is a part of "One World"

Core problem 2: Preservation of the natural fundamentals of life, of personal and other people's well being.

1 Ecological education - shaping the man-nature relation as a guideline for pedagogy

2 From subject lessons to cross curricular ecological education

In the last part of his speech Karpen explains the principles of the process. For each subject in each school stage a commission is made up.

Besides the teachers this commission will consist of representatives of parents and students, and experts from academicdisciplines and teacher education. Parts of the new curricula will be tested. The results of the testing will be fed back to the commissions.

In the documentation of the curricula revision, there is an organisation scheme, which shows the participants and their role in the process (Figure 4)

In the further course of the conference, papers were presented referring to the core problems. The headings of the papers are:

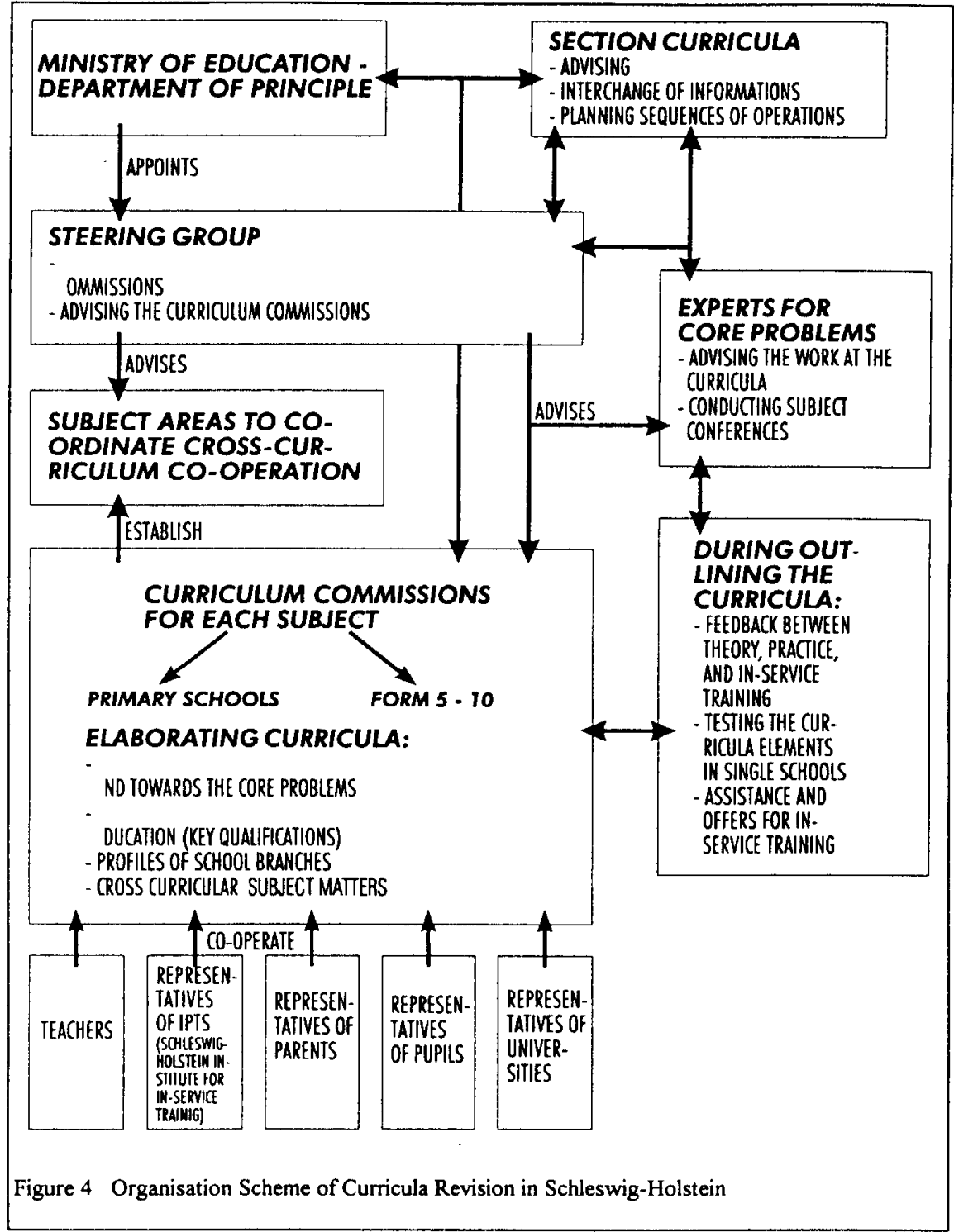

Core problem 1: Basic values of human living together, especially peace, human rights and living together in a world with different cultures, social systems, peoples, and nations to be an individual and global task.

1 Basic values of human living together and their
3 The future task of ecological education as a duty for all school subjects

4 Learning in a healthy way is more than learning health

Core problem 3: The future change in economic, technological, and social conditions of life and their 
impact on shaping conditions of life.

1 Landmarks for curricula revision SchleswigHolstein

2 Records of working group 1 (economics)

3 Records of working group 2 (social)

4 Records of working group 3 (new media)

Core problem 4: Equal status for women and men, boys and girls within the family, vocation and society.

1 Research outcomes relating to the gender issue - consequences for lessons and pre- and inservice training of teachers

2 Records of the working group "research outcomes relating to the gender issue"

3 Ianguage aspects of inequality and equality of gender

4 Unequal conditions for girls/women and boys/ men in the areas of science education and vocational orientation.

Core problem 5: The right of all human beings to organise their own political, cultural, and economic conditions of life, their participation and joint responsibility in all areas of life.

1 Social change and participation in society, economy, and politics

2 Intercultural education - charge and chance

3 Intercultural district schools - bilingual learning.

\section{Key qualifications}

- acquiring factual knowledge about technology

- acquiring ability to organise production in craftsman's or industrial ways

- acquiring safe ways of acting

- knowing fundamentals of order at a working place and in the workshop

- usingappropriate ways of working with materials, tools, machines, and devices

- making objects in an accurate way

- acquiring sensitivity towards sparing resources, using energy, avoiding waste, and recycling

- preparing ability to use technology in safe and appropriate ways

- bringing creativity into the solution of problems

- acquiringtechnological sensitivityandawareness of problems/learning transferable strategies

- acquiring ability to comprehend complex connected situations

- acquiring ability to evaluate technology

- acquiring decision competence in the area of pre vocational orientation

- acquiring ability to experience

- acquiring independence

- discovering and perceiving one's own capacities

- acquiring ability to work in teams and to accept each other in different situations

\section{Revising the Technology Curriculum}

The commission for technology education consists of 6 teachers (two each from Hauptschule, Realschule and Gesamtschule), a representative of parents, and a member of Flensburg University.

The main problem in the first sessions of the commission was the fact that teachers stuck to the old curriculum, which was very clearly formulated. (Figure 5) In particular the structure following the fields of action was a help for teachers in structuring the lessons. The core problems were rather understood as a sort of political indoctrination than a help to make a curriculum. But with the discussion going into the depth of the problems, members of the commission began to recognise that the core problems were realistic problems for the students in the present and in future. In this phase of the work some of the members of the commission quit co-operation and new members were selected. Selecting new members happened in agreement with the existing commission, candidates were invited for 'test' sessions.

\begin{tabular}{|c|c|c|c|}
\hline 7 & 8 & 9 & 10 \\
\hline $\begin{array}{l}\text {-Designing and manu- } \\
\text { facturing a wooden } \\
\text { object } \\
\text { Extensions: } \\
\text { - wood and wooden } \\
\text { materials } \\
\text { - technical drawing }\end{array}$ & $\begin{array}{l}\text { Work and } \\
\text { - Designing and mant- } \\
\text { facturing an object } \\
\text { from metal } \\
\text { Extensions: } \\
\text { - Standardisation of } \\
\text { metallic materials and } \\
\text { machine elements } \\
\text { - Expanding the basics } \\
\text { of tochrical drawing }\end{array}$ & 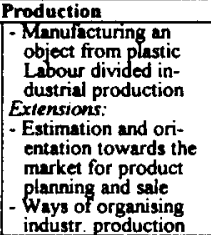 & $\begin{array}{l}\text { - Cassing in moulds } \\
\text { - Machines in produc- } \\
\text { tion processes From } \\
\text { simple tools to mod- } \\
\text { erm automata } \\
\text { Extension: } \\
\text { - Facilities for enhanc- } \\
\text { ing efficiency in pro- } \\
\text { duction }\end{array}$ \\
\hline $\begin{array}{l}\text {-Solving lechnological } \\
\text { problems of fifting } \\
\text { and conveying }\end{array}$ & $\begin{array}{l}\text { Transportatici } \\
\text { - Bicycle and moped, } \\
\text { proven means of } \\
\text { moving: analysis and } \\
\text { repiar, maintenance } \\
\text { end care } \\
\text { Exilension: } \\
\text { - Function and struc- } \\
\text { ture of selected ma- } \\
\text { chine etements }\end{array}$ & $\begin{array}{l}\text { on and Tramic } \\
\text { Anatysing and com- } \\
\text { paring transportation } \\
\text { and traffic systems }\end{array}$ & $\begin{array}{l}\text { - Technological de- } \\
\text { velopentit From the } \\
\text { carriage to modern } \\
\text { motor cars } \\
\text { Extension: } \\
\text { - Constructing and } \\
\text { analysing different } \\
\text { kinds of gearing }\end{array}$ \\
\hline $\begin{array}{l}\text { - Building simple load } \\
\text { bearing constructions } \\
\text { Extension: } \\
\text { - Comparing load } \\
\text { bearng constructions }\end{array}$ & $\begin{array}{l}\text { Building and Bu } \\
\text { - Concrete as abuild- } \\
\text { ing material Experi- } \\
\text { menting and manu- } \\
\text { facturing simple ob- } \\
\text { jects }\end{array}$ & $\begin{array}{l}\text { ilt Environment } \\
\text { Planning and realising } \\
\text { a simple real building } \\
\text { project }\end{array}$ & $\begin{array}{l}\text { - Comparing conven- } \\
\text { tional and industrial } \\
\text { ways of building } \\
\text { Extersions } \\
\text { - Unit construction } \\
\text { systems } \\
\text { - Heat protection and } \\
\text { using solar enerery in } \\
\text { passive devices }\end{array}$ \\
\hline $\begin{array}{l}\text { - Basic housce equip- } \\
\text { ment for supply and } \\
\text { waste management } \\
\text { Extrension: } \\
\text { - Heating systems }\end{array}$ & $\begin{array}{l}\text { Supply and W- } \\
\text { Examples of techno- } \\
\text { logical facilities to- } \\
\text { protect the envi- } \\
\text { ronment }\end{array}$ & 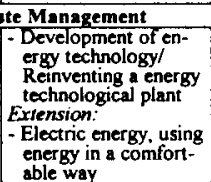 & $\begin{array}{l}\text { Constructing and } \\
\text { testing simple facili- } \\
\text { ties te exploit re- } \\
\text { generative sources of } \\
\text { energy }\end{array}$ \\
\hline $\begin{array}{l}\text { Canstructing testing } \\
\text { and compering sim- } \\
\text { ple devices to } \\
\text { transmit messages }\end{array}$ & $\begin{array}{l}\text { Information and } \\
\text { - Planing and manu- } \\
\text { facturing simple de- } \\
\text { vices to silve control } \\
\text { prroblems } \\
\text { Eriension: } \\
\text { - Different systems of } \\
\text { control technology }\end{array}$ & $\begin{array}{l}\text { Communication } \\
\text { - Automaling techno- } \\
\text { logical processess } \\
\text { with control tech- } \\
\text { nology } \\
\text { Extensions: } \\
\text { - Constructing and } \\
\text { using basic gigital } \\
\text { circuts } \\
\text { - Using computers for } \\
\text { control tasks }\end{array}$ & $\begin{array}{l}\text { Using computers to } \\
\text { solve specific tech- } \\
\text { nological problems }\end{array}$ \\
\hline
\end{tabular}

First the commission formulated key qualifications for technology education: 


\section{Rough objectives}

To show the connections of key qualifications with the core problems rough objectives were defined for each field of action.

The Student should be able to:

\section{Work and production}

- know the materials wood, metal, plastics, and ceramics as well as their main properties and determine their applicability for manufacturing planned work pieces.

- consider the problems of procuring and processing raw material under economic and ecological aspects.

- recognise the impacts of pollution in industrialised and non-industrialised countries and look for remedial measures in their own area.

- understand recycling/avoiding waste as processes with less harm to environment.

- understand school and household as avant-garde for a future oriented environment.

- know basic processes, materials, and tools in manufacturing and process technology and carry out simple processes.

- make and interpret technical drawings, mounting and operating instructions.

- outline, plan, and manufacture simple products.

- assess products and manufacturing processes.

- understand safety rules and apply them in every stage of the lesson.

- know fundamentals of organisation and automation of work processes in crafts and industry and transfer them to simple productions.

- recognise and assess impacts of labour division, mechanisation, and automation on working place, change of vocations and employment structure as well as the living-standard in an industrial society.

- test and assess technical products from a consumer's view.

- plan and use devices for multiple manufacturing.

- work appropriately and safely with selected tools, devices, and machine tools.

- know vocations from the areas material processing and manufacturing.

\section{Transportation and traffic}

- know and compare structure and function of selected systems for transportation and traffic.

- discuss the role of man as a part of the system.

- understand former and future development of systems for transportation and traffic.

- design and make models of conveyances.

- analyse real objects by dismantling and reassembling.
- recognise and assess the interactions and interdependence of advantage, safety, economic factors and ecological damage.

\section{Supply and waste management}

- know, present and describe technological systems of supply and waste management and judge them with economic and ecological criteria.

- outline, make and assess simple models and real objects of systems for supply and waste management

- explain the interdependence of the employment of raw material and energy on the one hand and of pollution on the other hand.

- know and judge former and present problems of supply and waste management in an industrial society, cleaning of air, water, and earth.

- know and apply possibilities of saving energy, avoiding waste and recycling.

- know, apply and assess sustainable systems of energy supply.

- know vocations from the area supply and waste management.

\section{Information and communication}

- design, make, test, and compare simple systems of information and communication.

- know selected former and present processes of control and information technology and assess their meaning for man

- design and make devices tocontrol technological processes.

- recognise and use controlling as a technological principle.

- automate simple processes with electric/ electronic circuits.

- know assess and judge the impact of automation on man in different areas of life.

- realise basic electric and electronic circuits of different stages of development.

- solve technological problems with logic circuits.

- apply computers to control processes and for drawing.

- know and assess flexible applications of computers for solving specific technological processes.

- design simple programs and modify ready-made programs to solve problems.

- analyse the impact of computers on different areas of life.

- know vocations in the areas of information and communication.

\section{Construction and built environment}

- know the main properties of important construction materials and assess their suitability in different areas of application. 
- know and apply basic principles of planning buildings under the aspects of the dimension and integration of rooms, cardinal point, soundabsorption and economy.

- read simple drawings and draw sketches.

- know basic principles of statics and construction.

- plan and execute simple construction projects in model or reality.

- recognise that the buildings must be both adapted to the need of man and environment friendly.

- know craftsman's and industrial ways of building, analyse and assess them.

- know basically the political planning processes as well as legislation.

- plan rooms under the aspects health, psychological effect, sociology, ecology, and economy.

- distinguish the "merchandise" dwelling from other merchandise.

- know vocations in the area of construction.

\section{Structure of the teaching units}

During the elaborating of the first units the way in which to integrate the reference to core problems was discussed. The following structure evolved:

Specification: the specification includes an orientation towards a target.

Reference to the core problems: the connections of the subject matter with the core problems are set forth.

Contribution of the subject matter to basic education: Here the multiple aspect view of the subject becomes clear. The commission developed a structure diagram to explain the fields of tension of the subject matter. This diagram also shows connecting points to cross curricular teaching.
Reference to keyqualifications/teaching intentions: The listed intentions connected with the subject matter are compulsory. They are oriented towards the key qualification.

\begin{tabular}{|c|c|c|c|c|}
\hline $\begin{array}{l}\text { Socio-technical } \\
\text { field of action }\end{array}$ & & & & \\
\hline $\begin{array}{l}\text { Work and pro- } \\
\text { duction }\end{array}$ & $\begin{array}{l}\text { Responsibility } \\
\text { of man working } \\
\text { with raw mate- } \\
\text { rial in craftsman } \\
\text { like production. } \\
\text { Basic course: } \\
\text { Communication } \\
\text { in technology. } \\
\text { 7. - 9. form }\end{array}$ & $\begin{array}{l}\text { Development } \\
\text { and employ- } \\
\text { ment of ma- } \\
\text { chines change } \\
\text { place of work } \\
\text { and vocation. } \\
\text { Interdependenc } \\
\text { e of man and } \\
\text { machine in pro- } \\
\text { duction. } \\
\text { 7. }-9 \text {. form }\end{array}$ & \begin{tabular}{|l|} 
Industrial pro- \\
duction of article \\
for daily use and \\
its impact on \\
conditions of life. \\
8.19 . form
\end{tabular} & \\
\hline $\begin{array}{l}\text { Transportation } \\
\text { and traffic }\end{array}$ & $\begin{array}{l}\text { Bicycle technol- } \\
\text { ogy and appro- } \\
\text { priate use of } \\
\text { means of trans- } \\
\text { port. } \\
\text { 7. form }\end{array}$ & $\begin{array}{l}\text { Car technology } \\
\text { and its interac- } \\
\text { tions with man } \\
\text { and environ- } \\
\text { ment. } \\
\text { 9. form }\end{array}$ & $\begin{array}{l}\text { Technology con- } \\
\text { ceptions for envi- } \\
\text { ronment conserv- } \\
\text { ing means of } \\
\text { transport. } \\
10 \text {. form/project }\end{array}$ & $\begin{array}{l}\text { People develop } \\
\text { technology (e.g. } \\
\text { air craft engineer- } \\
\text { ing) and use it in } \\
\text { different ways. } \\
8 .-10 \text {. form } \\
\end{array}$ \\
\hline $\begin{array}{l}\text { Construction - } \\
\text { built environment }\end{array}$ & $\begin{array}{l}\text { Former and pres- } \\
\text { ent ways of con- } \\
\text { structing bridges- } \\
\text { basic principles } \\
\text { of static, select- } \\
\text { ing materials, } \\
\text { impacts on man } \\
\text { and environment. } \\
7 \text {. form }\end{array}$ & $\begin{array}{l}\text { People protect } \\
\text { and secure them- } \\
\text { selves - safety } \\
\text { systems of yes- } \\
\text { terday, today, } \\
\text { and tomorrow. } \\
7 \text { - } 8 \text {. form }\end{array}$ & $\begin{array}{l}\text { Dwelling in } \\
\text { changing times - } \\
\text { ecologically } \\
\text { beneficial, hu- } \\
\text { man building } \\
\text { and living to- } \\
\text { gether. } \\
8 \text {. }-10 \text {. form/ } \\
\text { project }\end{array}$ & \\
\hline $\begin{array}{l}\text { Supply and waste } \\
\text { management }\end{array}$ & $\begin{array}{l}\text { Wrapping is a } \\
\text { burden for envi- } \\
\text { ronment - dispos- } \\
\text { ing and planning } \\
\text { wrappings, } \\
\text { avoiding refuse } \\
\text { through abolish- } \\
\text { ing, recycling } \\
\text { relieves environ- } \\
\text { ment. } \\
7 .-9 \text {. form }\end{array}$ & $\begin{array}{l}\text { Supplying and } \\
\text { disposing gar- } \\
\text { bage of a house- } \\
\text { hold under tech- } \\
\text { nological, eco- } \\
\text { logical and eco- } \\
\text { nomic aspects. } \\
\text { 8. - 9- form }\end{array}$ & $\begin{array}{l}\text { Using energy } \\
\text { efficiently and } \\
\text { sustainable en- } \\
\text { ergies in house- } \\
\text { holds. } \\
9.110 \text {. form }\end{array}$ & $\begin{array}{l}\text { Man as consumer } \\
\text { - discriminating } \\
\text { dealing with the } \\
\text { supply of techni- } \\
\text { cal articles - } \\
\text { analysing, testing, } \\
\text { and purchasing } \\
\text { products. } \\
9 . \text { - } 10 \text { form }\end{array}$ \\
\hline $\begin{array}{l}\text { Information and } \\
\text { communication }\end{array}$ & $\begin{array}{l}\text { Basic electrical } \\
\text { circuits and } \\
\text { safety education. } \\
\text { Basic course: } \\
\text { Soldering. } \\
\text { 7. form }\end{array}$ & $\begin{array}{l}\text { Impact of auto- } \\
\text { mation technol- } \\
\text { ogy on man, } \\
\text { working place } \\
\text { and vocation. } \\
\text { From hand con- } \\
\text { trol to comput- } \\
\text { ers } 70 \text { form } \\
7 \text {. - } 10 \text {. }\end{array}$ & $\begin{array}{l}\text { Interchange of } \\
\text { information, de- } \\
\text { velopment and } \\
\text { impacts. } \\
\text { From the drum to } \\
\text { wireless tele- } \\
\text { phones. } \\
8 .-10 . \text { form }\end{array}$ & $\begin{array}{l}\text { bold: compulsory } \\
\text { subject matters }\end{array}$ \\
\hline
\end{tabular}

Figure 6 The 1994 Technology Curriculum, Overview

Remarks referring to the subject matter / pedagogical remarks, cross curricular aspects: The subject matters should be understood as offers. The intentions can be worked out with other examples.

Once this preparatory work was done, the teaching units were worked out. The following overview shows them. (Figure 6)

The comparison of both surveys shows that the new curriculum is less rigid. It gives more freedom to the teacher to teach the matters in different ages. From the comparison is not visible that the new curriculum contains much more text toensure the reference to the core problems. The large amount of text was the reason why the dissemination has come out to be more difficult than that of the old curriculum. 


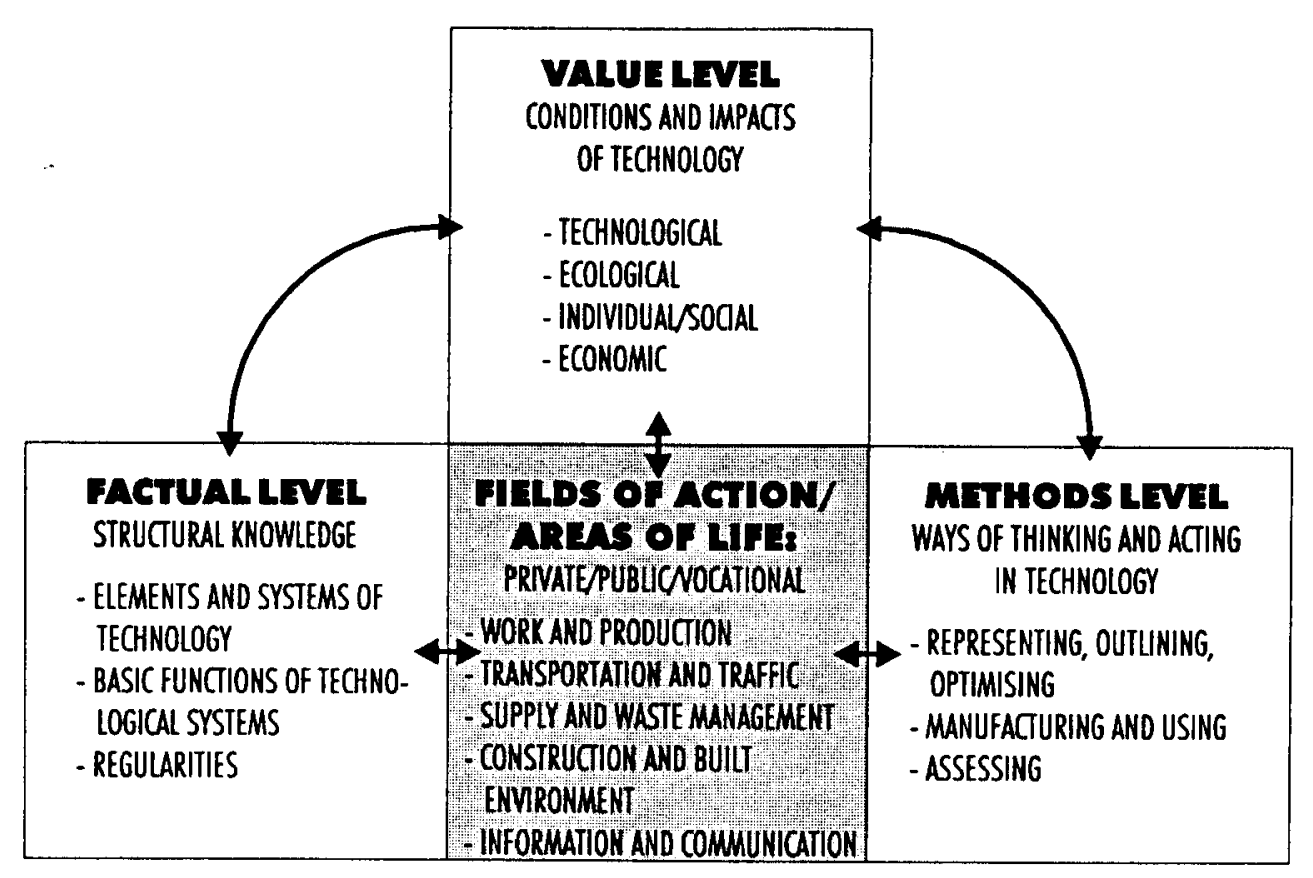

Figure 7 Didactical Structure of Technology Education

Teachers had to be introduced to the curriculum in in-service training courses. To facilitate spreading the curriculum, the commission developed graphic representations to show the intentions. The first presentation (fig. 7 ) shows the connections of the fields of action with the levels of technology education.

The second representation shows the interdependence of technological aspects with aspects affected by technology. Such a graphic representation was made for each teaching unit.

With these illustrations, the new curriculum grew again.

\section{Main differences between previous and new curriculum}

The previous curriculum had preliminaries explaining the targets of technologyeducation, comments on methods and media of teaching, remarks on planning and carrying out lessons, and an survey of the curriculum. This part consists of 18 pages.

In the new curriculum, this part contains a lot more of information (e.g. core problems) and amounts to 30 pages.

In the previous curriculum, the representation of the curriculum units takes 72 pages. The structure of these units is very simple: objectives, subject matter, and advice for teaching are presented in parallel.

The structure of the new curriculum is a little more complicated. As shown above, every unit has a preliminary note of its own. It contains a rather problem-oriented title than a short heading. The connection with the core problems is discussed, and references to the key qualifications are shown. After these preliminary notes advice for the subject

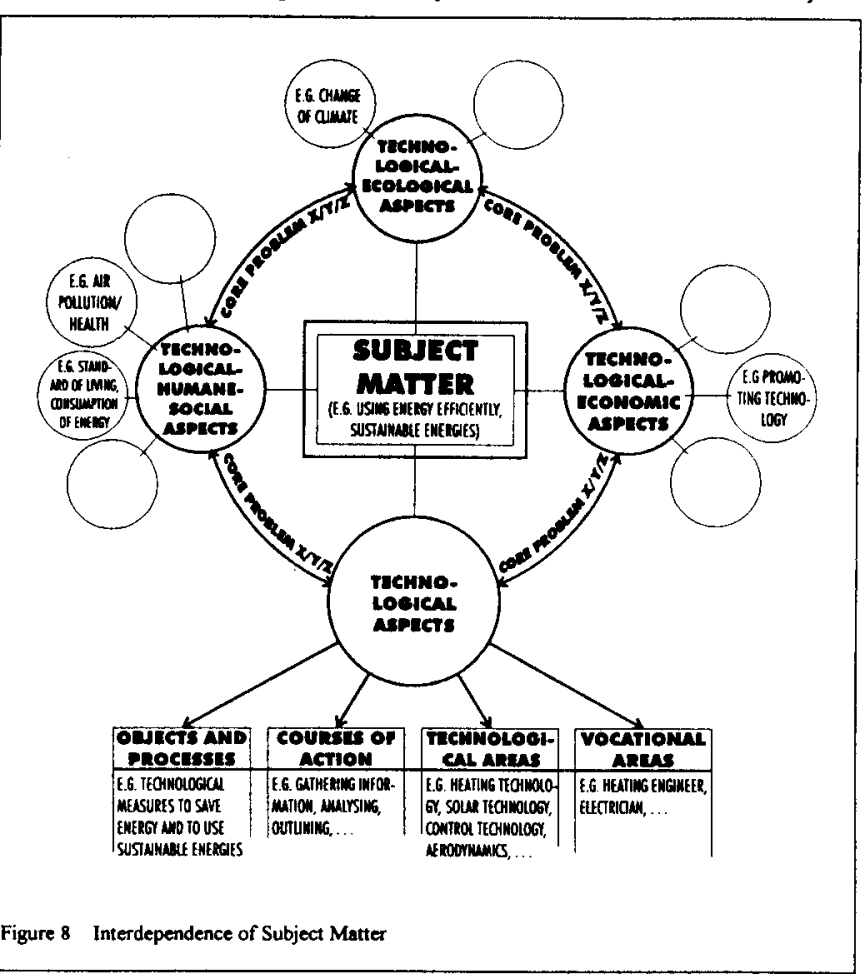


matter proposals are given. The teacher is always free to select other matters to meet the teaching intentions! Parallel to these proposals, teaching hints are offered, combined with suggestions for cross curricular work. Though the size of the units differ, they at least cover 16 pages each. (Not all are finished yet.) So all 17 curriculum units will sum up to approx. 300 pages in addition to the 30 pages preliminary notes.

\section{Conclusion}

The new curriculum tries toshow clearly the impacts and interdependencies of technology. With this intention they tend to become very complex. Teachers have problems translating them into lessons. They will need several courses of in-service training.

Attempts to integrate the new curriculum in preservice training seem to be more promising.

The new curriculum will not be valid until the commissions for all school subjects have finished their work. So the Schleswig-Holstein government can take some time to decide about the new curriculum.

\section{References}

1 Der Kultusminister des Landes SchleswigHolstein (ed.): Lebrplan Realscbule Technik. Kiel 1986 (Schmidt \& Klaunig)

2 Die Ministerin für Bildung, Wissenschaft, Kultur und Sport des Landes Schleswig-Holstein (ed.): Lebrplanrevision in Schleswig-Holstein. Kiel 1992

3 Schulte, H./Wolffgramm, H./Hartmann, E./Hein, Chr./Höpken, G.:Allgemeinetecbniscbe Bildung - Technikunterricht. Stuttgart 1991 (Klett)

4 LebrplanentwurfTecbnik Sekundarstufe I (not yet published) 